\title{
IMPROVEMENT OF PERSONAL SALES EFFICIENCY IN AUTOMOTIVE RETAILING
}

\begin{abstract}
Sale has existed for centuries, but the principles behind it have changed over time. Contemporary theory emphasizes increase of customer productivity through strategic sales organization that converges with marketing in order to achieve greater strategic importance in the organization. This study uses a qualitative research method (in-depth interviews) with the aim of determining the relationship between sales and marketing, as well as learning about the perceptions of sales managers on the definition of sales strategy and atmosphere design as variables that affect sales efficiency in automotive retailing. Research results from Bosnia and Herzegovina and Croatia were compared and they indicate a lack of coordination between marketing and sales efforts/departments, and the inadequate use of atmospheric factors in both of the observed markets.
\end{abstract}

Key words: personal selling, marketing, retail atmospherics, qualitative research

JEL Classification: M31, M53

\section{INTRODUCTION}

Sales evolution begun with transactional sales, where there are many repeated purchases that are made routinely, automatically, and based on knowledge of the characteristics of the product/service being purchased. This approach was very efficient and fast, but with disadvantages: the buyer focuses mainly at the price and it can be very difficult to launch new products or to encourage switching to new products with added value. In the late 60 's and early 70's, due to increased competition and complexity of leads, customers realized that transactional purchase provided non-optimal choice. The solution is consultative customer-oriented sales, with a strong recognition of needs based on the successful communication between buyer and seller (Manning and Reece, 2008). During the 80's, sales moved to strategic sales, in which companies began strategic sales planning. In the 90's, partnerships were created as strategic long-term relationships that solve the customer's problems by building relationships based on a win-win philosophy (Paparoidamis and Guenzi, 2009). Manning and Reece (2008) recommended a move towards the creation of value for the customer, where each sale has added value that strengthens the customer's experience through an improved creative selling process using technology and other contemporary tools.

Generating superior value for customers is based on building of a competitive advantage. The company creates superior value by offering benefits that are greater than the

\footnotetext{
${ }^{1}$ Senior Teaching Assistant at the School of Economics and Business, University of Sarajevo; Trg oslobodjenja - Alija Izetbegovic 1; email: selma.kadic@efsa.unsa.ba

${ }^{2}$ Assistant Professor at the Faculty of Economics and Business, University of Zagreb; Trg J.F. Kennedya 6; e-mail: mpalic@efzg.hr

3 Professor at the School of Economics and Business, University of Sarajevo; Trg oslobodjenja - Alija Izetbegovic 1; e-mail: $\underline{\text { muris.cicic@efsa.unsa.ba }}$
} 
costs that buyers must pay for a product or service. Superior value creates a competitive advantage and allows company to finance benefits from trade in the long term, which means that it creates such value more effectively and efficiently than its competitors (Slater and Narver 2000). A strong market-oriented organizational culture is an effective way to create superior value for customers (Day, 1994).

In today's competitive market, a sale is a critical element in an effort of modern companies to achieve organizational success based on consumer satisfaction, loyalty, and profitable sales volume (Anderson, 1996). In order to meet the needs of consumers, sales staff must work in cooperation with consumers as "helpers" rather than competing with them as the "persuaders" (Kirman and Campbell, 2004). This is why Manning and Reece (2008) considered that development of sales philosophy should involve three basic assumptions: the adoption of marketing concepts, evaluation of personal selling, and assumption of the role of problem solver, or a partner who helps the customer in making decisions.

As customers become more sophisticated and better informed (McDonald et al., 2000), the sales process was much less about the sale of products, and much more about the creation of relationships, which leads to involving the sales force in strategy creation through field information gathering and intelligence systems. Futurell defines the sales process as a sequential series of the seller's actions that leads towards buyers' desired activity and finishes with various forms of post-selling services that ensure the satisfaction of buying (Tomašević Lišanin 2010). It follows that sales management can be defined as the process of planning, implementing and monitoring the functions of personal selling (Cummings, 2004), which includes planning, finding and training staff, budgeting, developing compensation plans, and evaluating the effectiveness of the sales team (Manning and Reece, 2008).

Although different authors have observed the sales process differently and there are differences in relation to industry or types of products/services, most definitions include: identifying customers and their needs, preparing and arranging sales meetings, disclosure of customer needs and presenting solutions, handling objections, and possibly on the basis of a win-win philosophy, concluding the sale and post-selling services (Tomašević Lišanin 2010). The sales process is not time limited, and it is possible to successfully conduct all its phases in a short period or it can last for months or even years. Regardless of the stage in the process, the seller's goal is to successfully finish the current phase and to move to the next stage.

The strategic business plan of a company should be a guide for sale strategy. The strategic business plan includes strategies that the company uses for positioning in relation to the potential buyer before the sale even starts. On the other hand, the sales strategy is the plan of sales activities through methods of reaching clients, competitive differences and resources (Storbacka et al., 2009). Gosselin and Heena (2003) argue that a strategic deal with clients reported changes in the sales strategy, while Homburg and Pflesser (2000) go a step further by claiming that the new sales strategy leads to organizational changes in the company.

\section{DESIGNING ATMOSPHERE TO IMPACT BUYING BEHAVIOR}

Organizational changes in the company should consider broader usage of consumer perception knowledge with the aim to improve sales efficiency. In year 1973 Kotler wrote about the atmosphere at the selling point as one of the influential factors in creating the perceptions of consumers, as well as creating a stimulating retail environment for sales efficiency improvment. Kotler (1973) defines the atmosphere as a conscious space design that has effects on customers and clients. The atmosphere and environment of the retail space should be designed in a way that positively affects consumers' perception of the purchase and operation.

In the past thirty years several studies on the impact of atmosphere on buying behavior have been conducted. Donovan and Rossiter (1982) argue that emotional reactions are shaped by the environment at the point of sale in order to influence individuals to spend 
more money than they originally planned. According to the Mehrabian - Russell SOR model (stimulus - organism / condition - reaction), shown in Figure 1, stimuli from the environment influence consumers' emotional states, which in turn influences the behaviors of approach and avoidance. The outcome behavior of approach refers to the movement toward and behavior to avoid refers to the movement of different stimuli from the environment.

Figure 1: Model SOR (stimulus - organism / state - response)

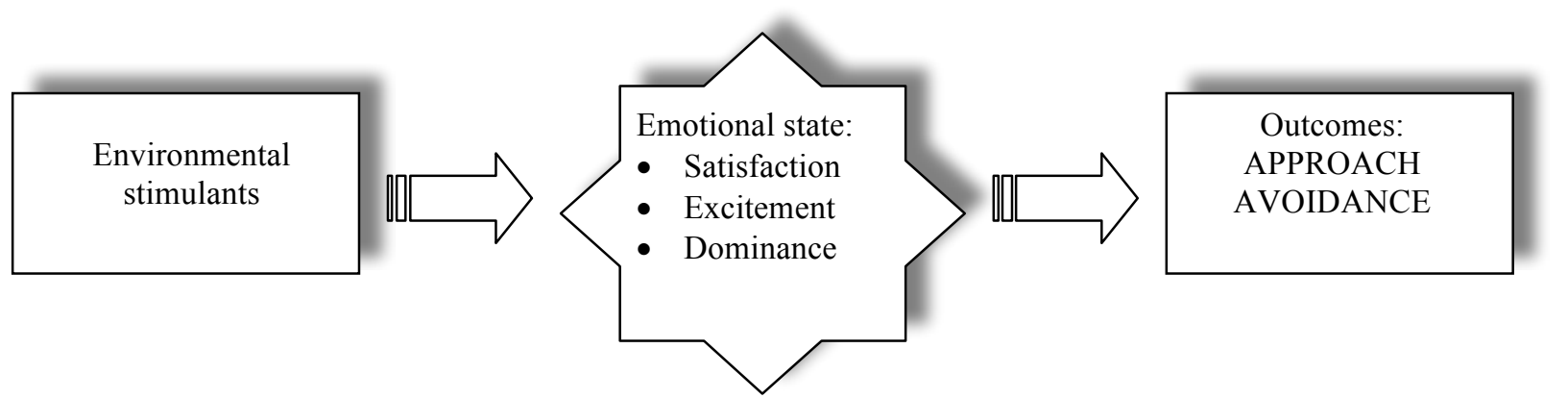

Source: Mehrabian, A., Russell, J.A. (1974) An Approach to Environmental Psychology: MIT Press, Cambridge, pp. 126

Knowing that $75 \%$ of emotions are associated with the sense of smell, and not with eyesight or hearing, it is clear that a brand, in order to survive, must provide special relations to the customer through complete sensory and emotional experience and connections to the products. Lindstrom (2005) proved that, if companies want to survive, brand management must evolve from a two-dimensional approach to a five-dimensional concept because more sensory information in the memory triggers a stronger connection to a brand.

The question is how to positively affect all of the human senses. Using music can attract the buyer's attention; shape and image can arouse certain emotions that will increase the possibility of buying. Studies (Gobe, 2006; Broekemier, Marquardt and Gentry, 2008) proved that music at the selling point, consistent with business objectives and target segment, may affect the buyer's desire to purchase and the time spent at the point of sale.

The sense of smell is the only sense that cannot be "turned off", because every breath leads to smell and this happens on average 20,000 times a day. Marketers believe that the key factor in brand sensing management is association with emotions. Some companies do not want to admit application of scent in their retail facilities because they are afraid of being accused for using subliminal perception, causing subconscious association to the brand and manipulating the selling environment with the aim of activating Pavlovian reactions among consumers (Trivedi, 2006). The sense of taste is closely linked to the sense of smell. For most companies it is difficult to incorporate taste into their brand. The most engaging sense that dominates in comparison to other senses is a vision (Lindstrom, 2005). Lighting can be considered a sales tool and can be used to attract customers, to focus on the product and to guide a purchase. Colors also affect the perception of the passage of time, as it seems that time slows down and that objects act bigger under a red light. In contrast, time passes quickly and items seams smaller under blue light.

All mentioned researchers indirectly confirmed that better cooperation between marketing and sales, regarding sharing knowledge on atmosphere design at the sales point, will improve sales efficiency.

\section{THE CONFLICT BETWEEN MARKETING AND SALES}

Although significant research efforts have been dedicated to the cooperation of functional departments in organizations, relatively little attention is paid to the inter-relation between sales and marketing. One reason for the neglect of this relationship is that customers typically see sales and marketing as functions serving the same goal (Cespedes, 1994; Le 
Meunier-Fitzhugh and Piercy, 2007). However, in practice it is often the case that when the sales are disappointing, marketing blames the sales force for a poor execution of the marketing plan. The sales team, however, argues that marketing set prices too high, and used an excessive budget. In this situation, sales departments believes that marketers are not in touch with what is really happening on the market, while marketers believe that the sales force is short-sighted, insufficiently aware of the market and blind to the future.

Many studies of the cross-functional relationship between sales and marketing have agreed upon existence of many negative characteristics of this relationship (Dawes and Massey, 2005), including poor coordination especially in planning and setting goals (Rouzies et al., 2005), strong misunderstanding, mistrust, poor co-operation and conflicts (Anderson, 1996). One reason for the lack of collaboration between sales and marketing is the variety of philosophies and backgrounds of the members in these teams (Ruekert and Walker, 1987; Cespedes, 1994, Kotler et al., 2006). Sales staff are often guided by intuition, while the marketers tend to be more analytical, data-oriented and focused on projects for building competitive advantages for the future. Front line staff, on the other hand, spend time talking to existing and potential customers, and they not only have an awareness of the customers' needs, but assume which products will experience maturity and which will not be successful. Sales staff earns money by closing the sale and it is much easier to determine success or failure, while the marketing budget is divided into programs, and more time is needed to determine the effects of the creation of long-term competitive advantage.

Kotler et al. (2006) states that any company can and should improve the relationship between sales and marketing. However, this sentence shows one of the most contentious relationships within organizations and there is a general consensus that the relationship between sales and marketing is poorly coordinated, and that improving this can be beneficial to the organization (Cespedes, 1993; Dewsnap and Jobber, 2007; Rouzies et al., 2005, Kotler et al., 2006). Tjosvold (1988) found that cooperation between these departments leads to improved productivity and competitiveness.

Kotler et al. (2006) conducted a research on relationship between sales and marketing, with the aim of identifying best practices that could help strengthen joint performance. They identified existence of four different types of relationships: undefined, defined, harmonized and integrated, where each has specific repercussions to the organization and business performance. The same methodological tool was used in this research to test one of the hypotheses.

When the relationship is undefined sales and marketing evolve independently, and each department is busy with its own tasks and programs. Each function does not know much about the activities, tasks and plans of the other function until the moment when conflict arises. Meetings between the two groups occurs ad hoc only with the aim of resolving conflicts, not because of proactive cooperation.

In a defined relationship the two functions establish processes and policies for the prevention of disputes through orientation that is reflected under the motto: "A good fence makes good neighbors." Retailers and marketers know who needs to do what and stick to their tasks. Groups begin to find common ground in potentially controversial areas. Meetings are more reflective, and the staff members ask questions of mutual cooperation and work together on large events.

A aligned relationship is characterized by clear but flexible boundaries between functions. Both functions take part in joint planning and training. The sales team understands and uses marketing terminology, while marketers work with vendors on the important matters.

When sales and marketing are integrated, the boundaries become blurred, and both functions redesign relationships to gain a larger share in the structure and systems of reward in companies. Marketing and sales focus on strategic tasks, which are oriented in advance. Marketers are deeply involved in the management of key customers, and jointly develop and implement performance metrics. Budgets become flexible and less controversial. 


\section{AUTOMOTIVE RETAIL MARKET IN BOSNIA AND HERZEGOVINA AND CROATIA}

During 2009, every major car brand reported a drastic sales decline, announced a reduction in production and cut down work force. A large part of the crisis in the automotive industry is associated with an increase in oil prices during the first part of 2008 and then by the raging financial and economic crisis that has swept the world. Part of the decline in demand is a result of the decline in consumption, caused by the impaired ability of banks to issue loans, and reduced consumer confidence. However, in early 2010, economists and experts predicted that market would overcome those difficult moments, and that the best producers would adjust and balance their businesses to the current demands, and that in the coming months they would be the best placed in global rankings of business.

In the first three months of 2010 there was a total increase in new car registrations in Europe by $9.2 \%$ (approximately 3.7 million new sold cars) compared to the first quarter of the previous year. Compared to the same period in 2008 these results represented a decline of $9.4 \%$ (Santini, 2010). In the first ten months of 2009, in Croatia 38,506 new passenger cars were registered, which is $50 \%$ less compared to the same period in 2008 (Suvremena.hr, 2009). In the first half of 2009 the decline in sales in the B\&H market was around $30 \%$. The reasons for the fall in demand in both countries are: the economic crisis, uncertainty and fear. Drop in car sales, according to the field's experts, are closely related to the fact that in the domestic market which depended on availability of financing, a new tougher restrictions imposed by financial institutions and higher interest rates dramatically reduced number of newly approved loans.

\section{RESEARCH METHODOLOGY}

The research focuses on the question whether it is possible to improve sales effectiveness through the improvement of relations between marketing and sales, specifically through defining sales strategy in the creation of atmosphere at the point of sale. The aim of this paper is to determine opportunities for improving the efficiency of sales, to investigate the perceptions of sales managers about working with their marketing departments, and to determine the importance of the atmosphere at the sale point using qualitative research.

In contrast to the linear research approach, which includes development of a research model before the research is carried out, a circular approach suggests that the theory should not be applied to the subject under investigation, but that it should rather be "discovered" and formulated during the research (Flick, 2009). This approach, characteristic of qualitative methods, forces researchers to continuously take care of the entire research process, and not simply the phase presently preoccupying the researcher.

Figure 2: Preview of the circular research approach 


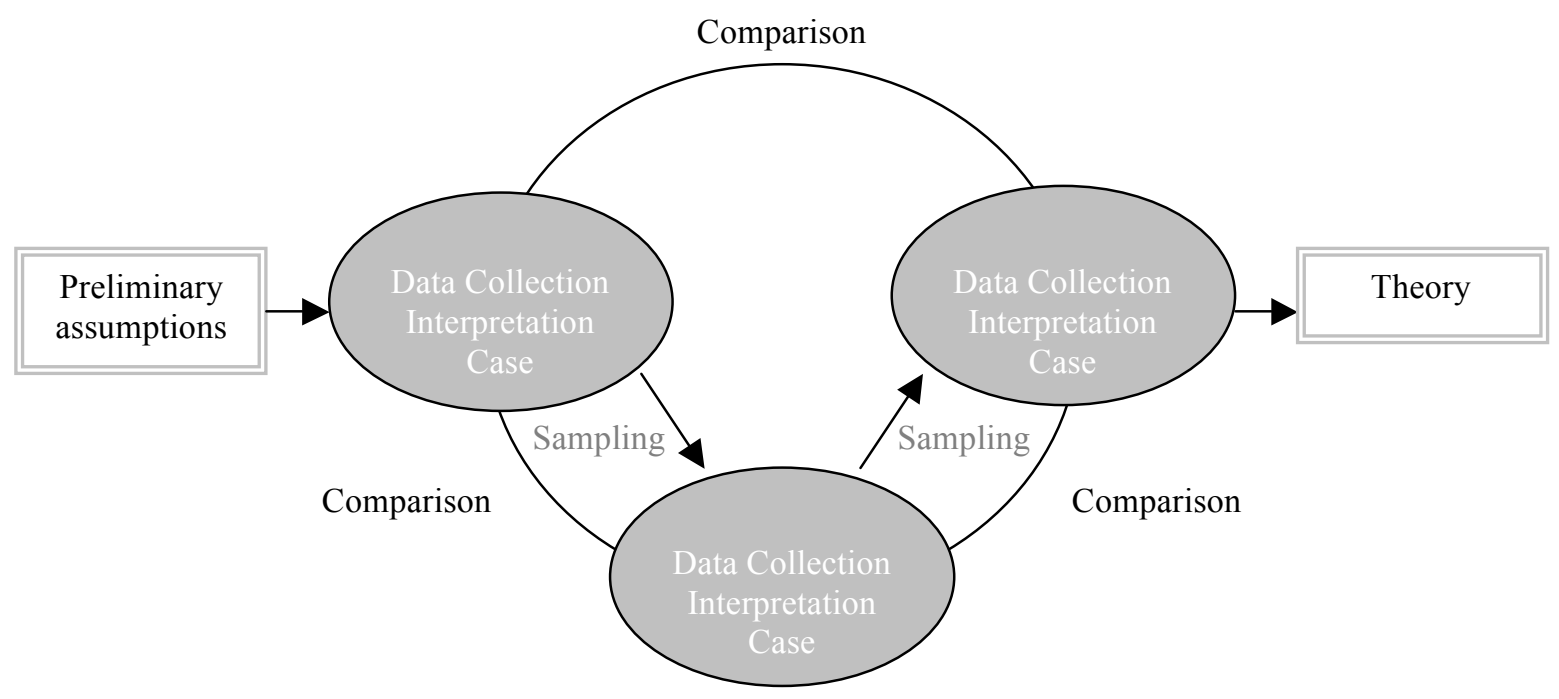

Source: Flick U. (2009) An Introduction to Qualitative Research, 4th ed.: SAGE Publications: pp. 95

In accordance with the object and purpose of research, the paper used a circular approach to qualitative research, considering in this analysis the most important motives and attitudes of sales managers. The following hypotheses were set:

- H1: Companies in the car retail sector in Bosnia and Herzegovina and Croatia do not have a retail strategy.

- $\quad \mathrm{H} 2$ : The relationship between marketing and sales departments in companies in the car retail sector in Bosnia and Herzegovina and Croatia ranges from "undefined" to "defined" and has all the repercussions of that particular relation to business operations.

- H3: Sales managers who are familiar with the influence of the atmosphere at the sales point to customers design stores so that customers can experience a sensory and emotional experience.

- H4: Sales managers believe that investments in the retail atmosphere will result in higher customer satisfaction and therefore increase sale efficiency.

The circular approach model for the research process suggests that the sample should be selected with regard to the relevance of certain persons for the issue, and not obtained as a statistically representative sample (Flick, 2009). Therefore, the selected respondents were the sales managers in ten companies in Bosnia and Herzegovina and Croatia engaged in automotive retail. Attention was paid that the sample represents companies that have a significant market share. Examining the data obtained from agencies involved in the retail car market research in both countries (Puls Promotion Agency Zagreb and Sarajevo Plus) showed that market shares for the same brands are similar in both countries. The selected representatives work in companies that sell the same five cars brands in both countries, as follows: three companies that are in both countries ranked between $1^{\text {st }}$ $7^{\text {th }}$ within the market share and two companies that were ranked between place $8^{\text {th }}-20^{\text {th }}$. It was ensured that the sample reflects the opinions of companies that have a total of around $40 \%$ of the market share in both countries.

Interviews were conducted through pre-formulated questions based on the data from the theoretical part of the paper and lasted between 60 and 120 minutes. The starting point for defining the research plan was the investigation of the electronic products sector conducted by Mallalieu and Nakamoto (2008). Questions were adapted to the car retail market, taking into account the significant changes that this market experienced during the recession.

During the interview, all participants were also asked to fill out questionnaire 
concerning relations between the sales and marketing departments in their company. The questionnaire used was developed by Kotler et al. (2006) as an objective tool for defining the relationship between the marketing and sales departments in a company. The questionnaire consists of 20 statements that can be ranked on the Likert scale of five degrees. By summarizing answers expressed numerically a result is obtained that reflects the relationship of these two departments in the company. According to Kotler (2006) it is possible to identify four types of relationships: undefined (questionnaire result between 20-39), defined (from 4059); harmonized (from 60-79), and integrated (from 80-100).

\section{ANALYSIS AND PRESENTATION OF RESULTS}

Distrust was noted among respondents regarding certain issues and topics. Distrust was increased with the fact that all conversations were recorded, and on the insistence of the respondents frequent interruptions occurred. However, respondents were willing to give answers to some questions on the condition that the recording stops. It was noted that respondents calculated with the questionnaire while giving grades for individual claims that were contradictory to what they previously said in the interview. In order to protect the anonymity of respondents a coding was made (Table 1).

Table 1: Coding

\begin{tabular}{|l|c|c|}
\hline Brand / Country & Croatia & Bosnia and Herzegovina \\
\hline Brand 1 & HR1 & BH1 \\
\hline Brand 2 & HR2 & BH2 \\
\hline Brand 3 & HR3 & BH3 \\
\hline Brand 4 & HR4 & BH4 \\
\hline Brand 5 & HR5 & BH5 \\
\hline
\end{tabular}

The different economic and political structures of $\mathrm{B} \& \mathrm{H}$ and Croatia, and their situations regarding EU integration, (entrance of Croatia is expected in 2012, while the status of Bosnia and Herzegovina is uncertain even in the next five years) was considered during the analysis.

Despite the differences in GDP per capita (for 2009: B\&H \$6,300 and Croatia $\$ 17,600)$ (CIA, 2010) it can be concluded that there was no significant difference in the way that companies are organized in those two countries, while differences were obvious between companies that compete in different price segments in the same country. The differences are even more obvious when it comes to attitudes towards the importance of the atmosphere at the point of sale.

The first part of the conversation with respondents concerned the companies' presentation, market share, and explanation of how the sales function is organized within the company. No respondents, except for HR1 and BiH1, could confirm that the company has a document called a "corporate business strategy", and therefore "retail strategy" was nonexistent as well. This document is usually replaced by a plan of sale, which is expressed quantitatively and financially. The realization of the plan is monitored monthly, quarterly and annually, and the plan is revised in line with market trends, as well as in line with global trends.

The next group of questions referred to the relationship between marketing and sales departments. Respondents showed a dose of fear in giving answers. Respondents defined cooperation as "correct" while some isolated responses clearly indicated that such qualification is far from the truth:

- The flow of information is not smooth and bilateral, and it is often reduced to the submission of the required information on one or the other side, where there is usually no feedback from the receiving side;

- Marketing departments do not fully understand needs of the target segment; 
- There are reports (weekly, monthly) that the sales department delivers to the marketing department (number of visitors, the number of calls, where potential buyers find information about the current promotion, etc.), but sales departments do not feel that the information collected is used properly.

All respondents completed a questionnaire that examines the relationship between the sales and marketing departments in the company (Annex 1). Results show that in six companies the relationship between sales and marketing achieved rank of "defined" (HR2, HR3, HR5, BH2, BH3, BH4). On the other hand, in four companies it seems that this relationship tends to be "aligned" (HR1, HR4, and BH1 BH5). It is interesting that there are no major differences between the arithmetic mean of respondents' regarding the country (Figure 3).

Figure 3: Arithmetic mean of the sales managers' responses by country

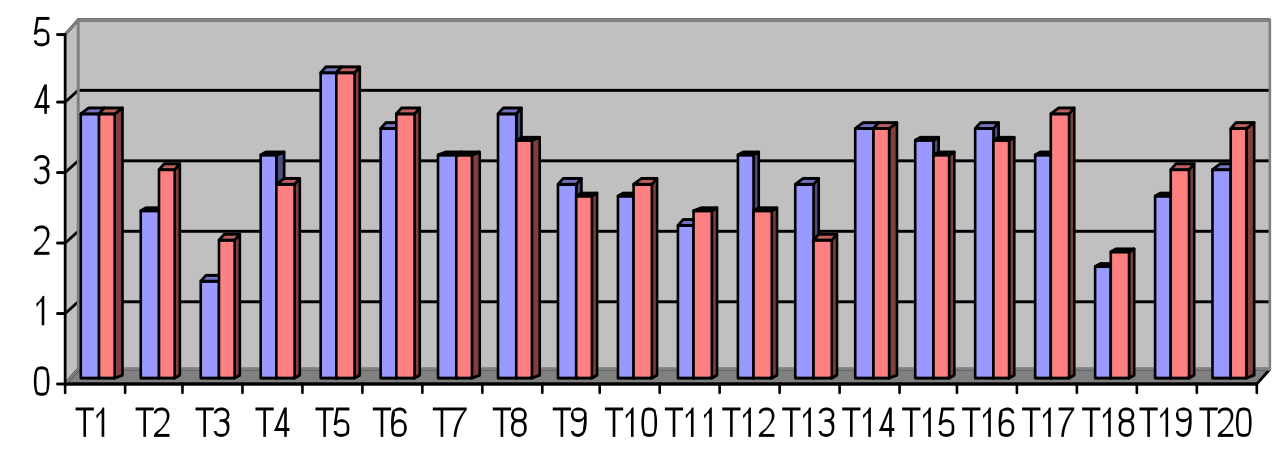

\section{$\square \mathrm{HR} \square \mathrm{BiH}$}

A fully balanced, relatively high average value supported the following claims: that the sales figures are usually at the level of the plan $(\mathrm{T} 1=3.8)$, that the sales force believes that assistance from the marketing department is an important tool for achieving better sales results $(\mathrm{T} 5=4,4)$, that the marketing and sales departments can tell that they "speak the same language" ( $\mathrm{T} 7=3.2)$, and that sales and marketing manage their activities using a process developed in common, as well as procedures to increase the range of business, from initial identification to serving users $(\mathrm{T} 14=3.6)$. However, the greatest discrepancy between the responses of sales managers in B\&H compared to Croatia was observed in claim 12: that sales and marketing discuss and use the same measures for evaluating performance results, where HR managers graded the claim 3.2 while B\&H managers graded it 2.4.

Significant difference in the respondents' answers was observed by comparing answers coming from managers whose companies sell cars in different price segments in both countries (Figure 4).

Figure 4: Answers sorted by price segments companies compete in 


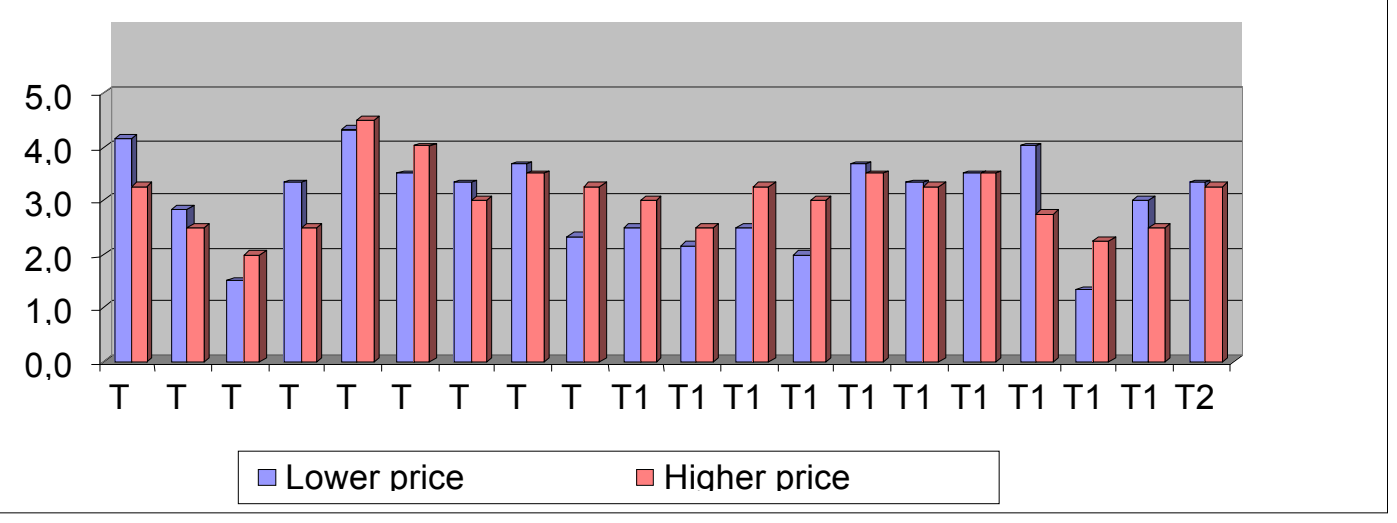

The answer values are, in most cases, higher among managers in a "added value" segment. The biggest difference is in claim 13, that the marketing department is actively involved in defining and executing sales strategies for individual sales managers, where sales managers in a higher price segment graded it 3.0, while managers in a lower price segment graded it 2.0 on average.

The last part of the interview referred to the atmosphere of the place of purchase. For all respondents the term "atmosphere at the sale point", evokes the atmosphere created by its sales staff. After the explanations, all respondents confirmed the presence of interior standards and exterior decoration of the dealership defined by the principal. The minimum standards are that the company must ensure the upgrading and improving of the interior is left to each partner. This was an obvious division between brands belonging to higher and lower price segments. Respondents dealing with a lower price class completely ignored environmental factors, emphasizing the atmosphere created by sales staff as crucial. The theory of fifth-dimension brand management was viewed as irrelevant to sales efficiency, while they agreed that investment in training sales staff, and designing an atmosphere for the sale point may result in increased customer satisfaction. On the other hand respondents HR4, $\mathrm{BH} 4, \mathrm{HR} 5$ and $\mathrm{BH} 5$, gave great importance to fifth-dimension regulation of the sale point and gave an example in which the right atmosphere at the point of sale (environmental factors) led to the positive completion of the sale process. Special importance was placed on creating personal relationships with customers, as well as on organizing special events for different customer segments. However, it is necessary to mention that, although they emphasized the importance of music at the sales point, only one of them had music on (through local radio stations).

The respondents whose companies engaged in retailing of higher price class brands pointed out that it was possible to increase sales in the last five years (especially in 2007 and 2008) by virtue of research into the atmosphere at the sale point, as well as the training of sales staff in the field of sales tactics. On the other hand, respondents that manage sales of brands that are lower priced believed that sales growth may be primarily due to price, quality of product and the service of sales staff.

\section{TESTING AND EXAMINATION OF HYPOTHESES}

None of the respondents explicitly confirmed the existence of a document called "retail strategy", which was substituted with occasional sales and financial plans. Therefore, if a retail strategy does not exist, then it is impossible to speak of the specifics of this strategy in terms of combining sales tactics and the atmosphere of the place of purchase. It follows that $\mathrm{H} 1$ is confirmed.

The second hypothesis concerns the relationship between marketing and sales departments in retail automotive companies in Bosnia and Herzegovina and Croatia. The 
conclusions were very contradictory. Results obtained from the questionnaire point toward conclusion that the relationships between sales and marketing range from "defined" to "coordinated." At the same time, during the interviews respondents cited a variety of communication problems with their marketing departments which were manifested through the following: obtaining the right information at the right time, obtaining a response to reports submitted, and not knowing the characteristics of the target segment. All of the difficulties mentioned should not be present in organizations whose marketing and sales departments have a defined relationship that tends to be "aligned." Knowing that respondents were slightly calculated when answering the questionnaire, the authors believe that it is necessary that all responses from the questionnaires should be corrected i.e. downgraded. Such a move would support the second hypothesis. However, it is impossible to claim that $\mathrm{H} 2$ is fully confirmed.

Some respondents ( $\mathrm{HR} 3$, and $\mathrm{BiH} 3, \mathrm{BiH} 5)$ were aware of the influence of atmosphere on customers, and they tried to design it in a way that customers are provided with positive sensory and emotional experience. Other respondents considered it completely irrelevant or less important in their particular industry. Respondents agreed that investment in sales staff training and designing sales point atmosphere probably would result in customer satisfaction, while opinions on the growth of sales caused by this investment were diametrically opposed, and range from absolute confirmation (companies in a higher price segment) to absolute denial (companies in a lower price segment). It was obvious that no company has a plan to invest in an atmosphere at the sale point, nor to measure the effects of these investments on satisfaction and sales. It can be concluded that H3 is confirmed while H4 is partly confirmed.

\section{CONCLUSION}

In a dynamic environment, competition increases and market conditions make knowledge one of the most valuable resources for a company. It is obvious that companies in the automotive retail sector are facing the worst crisis in its history. However, this study confirmed the hypothesis that in such circumstances, enterprises in both Bosnia and Herzegovina and Croatia completely lack retail strategies. Research has shown that the information flow between marketing and sales is jammed. This applies to the fact that the sales managers were afraid to negatively evaluate the work of marketing departments in the survey. They shared a fear that colleagues from marketing department will see their survey. All those lead to the termination that relationship between marketing and sales is far from "integrated", as it should be. The relationship tends to be in the middle from "defined" to "aligned".

Through the research the existence of two types of marketing strategies has been identified. One is based on price and the benefits that the buyer gets by the purchase of certain vehicles, which is irrelevant to other variables such as the sales point atmosphere. Nevertheless, such companies are working on building brands through the transfer of benefits that the customer achieves by cost savings in other spheres, and this strategy has proven effective. In contrast are companies that based their marketing strategy on balanced investment in other variables in order to create and improve brand image in the minds of consumers and charge a premium for the brand offered.

The scientific validity of this research is associated with a significant growth trend regarding importance of cross functional cooperation in the retail companies. The paper can serve to retail businesses in assessing the practical application of theoretical statements, allowing managers to think creatively and enhance their and knowledge of their employees. Research findings can be used for future work on a similar topic as a basis for qualitative research because of the lack of literature and data related to this area, particularly in Bosnia and Herzegovina and Croatia. In order to obtain full analyze, larger number of respondents from both countries is required. This would enable quantitative test of the hypotheses for both 
countries and a more detailed analysis of the differences in set hypotheses between the two countries.

Having in mind all current difficulties for retailers in the automotive sector the best companies will remain those that demonstrate flexibility in creating the atmosphere of the sales point as result of sharing knowledge between marketing and sales department

\section{LITERATURE}

Analiza tržišnog učešća na tržištu novih automobila u BiH 2008 - 2009. (2010), Agencija Plus, Sarajevo

Analiza tržišnih udjela na tržištu novih automobila u Hrvatskoj 2006 - 2009. (2010), Promocija Puls, Zagreb

Anderson, R.E. (1996) Personal selling and sales management in the new millennium. Journal of Personal Selling and Sales Management, Vol. 16, Fall, pp 1-16.

Broekemier, G., Marquardt R., Gentry, J.W. (2008) An exploration of happy/sad and liked/disliked music effects on shopping intentions in a women's clothing store service setting, Journal of Services Marketing, Volume: 22; Issue: 1

CIA, (2010) The World Fact book [online] Dostupno na: https://www.cia.gov/library/publications/the-world-factbook/[01. svibnja 2010.]

Day G.S. (1994) The capabilities of market-driven organizations, Journal of Marketing, 58 (4) pp. 37-52.

Dewsnap, B., Jobber, D. (2007) Testing a model of marketing-sales relations. Academy of Marketing Conference. July, Kingston, UK

Donovan, R.J., Rossiter, J.R. (1982) Store Atmosphere: An Enviromental Psychology Approach; Journal of Retailing; Vol. 58 pp. 34-57.

Flick, U. (2009), An Introduction to Qualitative Research, SAGE Publications Ltd; Fourth edition

Gobe, Mark (2006) Emocionalno Brendiranje; Mass Media International Beograd, ISBN: 86906723-3-8

Gosselin, D., Heene, A. (2003) A competence-based analysis of account management: Implications for a customer-focused organization. Journal of Selling and Major Account Management, Vol. 5 No. 1, pp 11-31.

Homburg C., Pflesser C. (2000) A multiple-layer model of market oriented organizational culture: measurement issues and performance outcomes. Journal of Marketing Research, 37. pp 449-62.

Kirmani, A., Campbell M.C. (2004) Goal Seeker and Persuasion Sentry: How Consumer Targets Respond to Interpersonal Marketing Persuasion. Journal of Consumer Research, 31, pp 9-31.

Kotler, P. (1973) Atmospherics as a marketing tool. Journal of Retailing, Vol. 49 No.4, pp 48-61.

Kotler, P., Rackham, N., Krishnaswamy, S. (2006) Ending the war between sales and marketing. Harvard Business Review, Vol. 84 No. 7/8, pp 68-78.

Le Meunier-Fitzhugh, K., Piercy, N.F. (2007) Exploring collaboration between sales and marketing. European Journal of Marketing, Vol. 41 No 7/8, pp 939-55.

Leigh, T.W., Marshall, G.W. (2001) Research priorities in sales strategy and performance. Journal of Personal Selling and Sales Management, Vol. 21 No. 2, pp 83-93.

Lindstrom, M. (2005) Brand Sense. Free Press. New York.

Manning, G.L., Reece, B.L., (2008) Suvremena prodaja: stvaranje vrijednosti za kupca. Mate. Zagreb.

Mallalieu L., Nakamoto K. (2008) Understanding the Role of Consumer Motivation and Salesperson Behavior in Inducing Positive Cognitive and Emotional Responses During a Sales Encounter. Journal of Marketing Theory and Practice, vol. 16, no. 3, pp 183-197. 
McDonald, M., Rogers, B., Woodburn, D. (2000) Key Customers: How to Manage them Profitably. Butterworth-Heinemann. Oxford.

Mehrabian, A., Russell, J.A. (1974) An Approach to Environmental Psychology. MIT Press. Cambridge.

Piercy, N.F. (2006) The strategic sales organization. The Marketing Review, Vol. 6, pp 3-28.

Paparoidamis N.G., Guenzi P. (2009) An empirical investigation into the impact of relationship selling and LMX on salespeople's behaviours and sales effectiveness. European Journal of Marketing, Vol. 43 No. 7/8, pp 1053-1075

Ruekert, R.W., Walker, O.C. Jr (1987) Marketing's interaction with other functional units: a conceptual framework and empirical evidence. Journal of Marketing, Vol. 51 No. 1, pp 1-19. Santini M. (2010) Stižu crni dani za europsko tržište automobila [online]. Jutarnji list.Dostupno na: http://www.jutarnji.hr/stizu-crni-dani-za-europsko-trzisteautomobila/730141/[01. svibnja 2010.]

Slater S.F., Narver J.C. (2000) Intelligence generation and superior customer value. $J$ Acad Mark Sci, 28(1), pp 120-127.

Suvremena.hr (2009) Hrvatska: Pad prodaje automobila za 50 posto [online] Suvremena.hr Portal za trgovinu. Dostupno na: http://www.suvremena.hr/13054.aspx[01. svibnja 2010.]

TomaševićLišanin, M. (2010) Profesionalna prodaja i pregovaranje. HUPUP, Zagreb.

Trivedi, B. (2006) Recruiting smell for the hard sell [online] NewScientist magazine. Dostupno na: http://www.newscientist.com/article/mg19225821.800-recruiting-smell-for-thehard-sell.html?full=true; [03. March 2010.]

Annex 1: Arithmetic mean of the questionnaires' answers

\begin{tabular}{|c|l|c|c|c|c|c|c|c|c|c|c|c|}
\hline$\#$ & Claim & $\begin{array}{c}\mathrm{HR} \\
1\end{array}$ & $\begin{array}{c}\mathrm{HR} \\
2\end{array}$ & $\begin{array}{c}\mathrm{HR} \\
3\end{array}$ & $\begin{array}{c}\mathrm{HR} \\
4\end{array}$ & $\begin{array}{c}\mathrm{HR} \\
5\end{array}$ & $\begin{array}{c}\mathrm{BH} \\
1\end{array}$ & $\begin{array}{c}\mathrm{BH} \\
2\end{array}$ & $\begin{array}{c}\mathrm{BH} \\
3\end{array}$ & $\begin{array}{c}\mathrm{BH} \\
4\end{array}$ & $\begin{array}{c}\mathrm{BH} \\
5\end{array}$ & $\begin{array}{c}\text { Avr } \\
\text { age }\end{array}$ \\
\hline 1 & $\begin{array}{l}\text { Our sales figures are usually close to } \\
\text { the sales forecast. }\end{array}$ & 5 & 3 & 5 & 2 & 4 & 4 & 4 & 4 & 3 & 4 & $\mathbf{3 , 8}$ \\
\hline $\begin{array}{l}\text { If things go wrong, or results are } \\
\text { disappointing, neither function points } \\
\text { fingers or blames the other. }\end{array}$ & 1 & 2 & 3 & 4 & 2 & 5 & 3 & 3 & 2 & 2 & $\mathbf{2 , 7}$ \\
\hline
\end{tabular}




\begin{tabular}{|c|c|c|c|c|c|c|c|c|c|c|c|c|}
\hline 3 & $\begin{array}{l}\text { Marketing people often meet with key } \\
\text { customers during the sales process. }\end{array}$ & 2 & 1 & 1 & 2 & 1 & 3 & 1 & 1 & 2 & 3 & 1,7 \\
\hline 4 & $\begin{array}{l}\text { Marketing solicits participation from } \\
\text { Sales in drafting the marketing plan. }\end{array}$ & 5 & 2 & 3 & 4 & 2 & 5 & 2 & 3 & 2 & 2 & 3 \\
\hline 5 & $\begin{array}{l}\text { Our salespeople believe the collateral } \\
\text { supplied by Marketing is a valuable } \\
\text { tool to help them get more sales. }\end{array}$ & 4 & 4 & 5 & 5 & 4 & 5 & 3 & 5 & 4 & 5 & 4,4 \\
\hline 6 & $\begin{array}{l}\text { The sales force willingly cooperates in } \\
\text { supplying feedback requested by } \\
\text { Marketing. }\end{array}$ & 3 & 4 & 3 & 4 & 4 & 5 & 3 & 3 & 5 & 3 & 3,7 \\
\hline 7 & $\begin{array}{l}\text { There is a great deal of common } \\
\text { language here between Sales and } \\
\text { Marketing. }\end{array}$ & 5 & 3 & 2 & 3 & 3 & 5 & 3 & 2 & 3 & 3 & 3,2 \\
\hline 8 & $\begin{array}{l}\text { The heads of Sales and Marketing } \\
\text { regularly confer about upstream issues } \\
\text { such as idea generation, market } \\
\text { sensing, and product development } \\
\text { strategy. }\end{array}$ & 5 & 4 & 3 & 4 & 3 & 5 & 2 & 3 & 3 & 4 & 3,6 \\
\hline 9 & $\begin{array}{l}\text { Sales and Marketing work closely } \\
\text { together to define segment buying } \\
\text { behavior. }\end{array}$ & 2 & 3 & 2 & 4 & 3 & 3 & 2 & 2 & 3 & 3 & 2,7 \\
\hline 10 & $\begin{array}{l}\text { When Sales and Marketing meet, they } \\
\text { do not need to spend much time on } \\
\text { dispute resolution and crisis } \\
\text { management. }\end{array}$ & 3 & 2 & 2 & 4 & 2 & 3 & 3 & 2 & 2 & 4 & 2,7 \\
\hline 11 & $\begin{array}{l}\text { The heads of Sales and Marketing } \\
\text { work together on business planning } \\
\text { for products and services that will not } \\
\text { be launched for two or more years. }\end{array}$ & 4 & 1 & 1 & 4 & 1 & 4 & 2 & 1 & 1 & 4 & 2,3 \\
\hline 12 & $\begin{array}{l}\text { We discuss and use common metrics } \\
\text { for determining the success of Sales } \\
\text { and Marketing. }\end{array}$ & 5 & 3 & 2 & 4 & 2 & 1 & 2 & 2 & 3 & 4 & 2,8 \\
\hline 13 & $\begin{array}{l}\text { Marketing actively participates in } \\
\text { defining and executing the sales } \\
\text { strategy for individual key accounts. }\end{array}$ & 2 & 3 & 2 & 4 & 3 & 1 & 2 & 2 & 3 & 2 & 2,4 \\
\hline 14 & $\begin{array}{l}\text { Sales and Marketing manage their } \\
\text { activities using jointly developed } \\
\text { business funnels, processes, or } \\
\text { pipelines that span the business chain } \\
\text { - from initial market sensing to } \\
\text { customer service. }\end{array}$ & 5 & 3 & 3 & 3 & 4 & 5 & 3 & 3 & 3 & 4 & 3,6 \\
\hline 15 & $\begin{array}{l}\text { Marketing makes a significant } \\
\text { contribution to analyzing data from } \\
\text { the sales funnel and using those data } \\
\text { to improve the predictability and } \\
\text { effectiveness of the funnel. }\end{array}$ & 4 & 3 & 3 & 4 & 3 & 4 & 3 & 3 & 4 & 2 & $\mathbf{3 , 3}$ \\
\hline 16 & $\begin{array}{l}\text { Sales and Marketing share a strong } \\
\text { "We rise or fall together" culture. }\end{array}$ & 5 & 3 & 3 & 4 & 3 & 5 & 2 & 3 & 3 & 4 & 3,5 \\
\hline 17 & $\begin{array}{l}\text { Sales and Marketing report to a single } \\
\text { chief customer officer, chief revenue } \\
\text { officer, or equivalent C-level } \\
\text { executive. }\end{array}$ & 5 & 2 & 4 & 3 & 2 & 5 & 4 & 4 & 4 & 2 & 3,5 \\
\hline 18 & $\begin{array}{l}\text { There's significant interchange of } \\
\text { people between Sales and Marketing. }\end{array}$ & 1 & 2 & 1 & 2 & 2 & 1 & 2 & 1 & 2 & 3 & 1,7 \\
\hline 19 & $\begin{array}{l}\text { Sales and Marketing jointly develop } \\
\text { and deploy training programs, events, } \\
\text { and learning opportunities for their }\end{array}$ & 2 & 2 & 3 & 4 & 2 & 5 & 3 & 3 & 2 & 2 & 2,8 \\
\hline
\end{tabular}




\begin{tabular}{|l|l|c|c|c|c|c|c|c|c|c|c|c|} 
& respective staffs. & & & & & & & & & & \\
\hline 20 & $\begin{array}{l}\text { Sales and Marketing actively } \\
\text { participate in the preparation and } \\
\text { presentation of each other's plans to } \\
\text { top executives. }\end{array}$ & 3 & 3 & 3 & 4 & 2 & 5 & 3 & 3 & 3 & 4 & $\mathbf{3 , 3}$ \\
\hline & SUMA & $\mathbf{7 1}$ & $\mathbf{5 3}$ & $\mathbf{5 4}$ & $\mathbf{7 2}$ & $\mathbf{5 2}$ & $\mathbf{7 9}$ & $\mathbf{5 2}$ & $\mathbf{5 3}$ & $\mathbf{5 7}$ & $\mathbf{6 4}$ & \\
\hline
\end{tabular}

\section{UNAPREĐENJE UČINKOVITOSTI OSOBNE PRODAJE U SEKTORU MALOPRODAJE AUTOMOBILA}

\section{SA ŽETAK}

Prodaja postoji od početka robne razmjene, ali su se principi $s$ vremenom promijenili. Suvremena prodaja u fokus stavlja povećanje produktivnosti kupca kroz stratešku prodajnu organizaciju koja konvergira s marketingom kako bi dobila veći strateški značaj u organizaciji. Kvalitativnim istraživanjem, metodom dubinskog intervjua, cilj rada je utvrditi odnos između prodajnog $i$ marketing odjela kao $i$ saznati više o percepciji prodajnih menadžera o definiranju strategije prodaje i oblikovanja atmosfere prodajnog mjesta kao jedne od varijabli koja može utjecati na efikasnost prodaje, na slučaju maloprodaje automobila. Komparirani su rezultati istraživanja u Bosni i Hercegovini i Republici Hrvatskoj, te oni općenito ukazuju na nedovoljnu povezanost između marketinga i prodaje, te na nedostatno korištenje atmosferskih čimbenika pri prodaji na oba promatrana tržišta.

Ključne riječi: osobna prodaja, marketing, atmosfera na prodajnom mjestu, kvalitativno istraživanje

JEL klasifikacija: M31, M53 